\title{
Assessing the effectiveness of the Great Australian Bight Marine Park in protecting the endangered Australian sea lion Neophoca cinerea from bycatch mortality in shark gillnets
}

\author{
D. J. Hamer ${ }^{1,2, *}$, T. M. Ward ${ }^{2,3}$, P. D. Shaughnessy ${ }^{4}$, S. R. Clark ${ }^{5}$ \\ ${ }^{1}$ Australian Marine Mammal Centre, Australian Antarctic Division, 203 Channel Highway, Kingston, Tasmania 7050, Australia \\ ${ }^{2}$ University of Adelaide, North Terrace, Adelaide, South Australia 5000, Australia \\ ${ }^{3}$ South Australian Research and Development Institute - Aquatic Sciences, 2 Hamra Avenue, West Beach, \\ South Australia 5024, Australia \\ ${ }^{4}$ South Australian Museum, North Terrace, Adelaide, South Australia 5000, Australia \\ ${ }^{5}$ Department for Environment and Heritage, Liverpool Street, Port Lincoln, South Australia 5606, Australia
}

\begin{abstract}
The Endangered Australian sea lion Neophoca cinerea occurs in low numbers, exhibits low fecundity, extreme philopatry and substantial population genetic structure at the breeding colony level. These traits may increase susceptibility to population decline, with additional mortality as bycatch in shark gillnets being a possible threat. The Great Australian Bight Marine Park (GABMP) was established, in part, to protect the small and remote Bunda Cliffs population from anthropogenic impacts such as commercial fishing. This study investigated the effectiveness of the GABMP in reducing spatial overlap between Australian sea lions and gillnets and in preventing bycatch. An independent fishery observer program reported a mortality rate of 0.0206 individuals (ind.) $\mathrm{km}^{-1}$ of gillnet set within the GABMP, amounting to between 4 and 15 (confidence bounds of standard error of the estimate) ind. killed there during the most recent breeding cycle. A mortality rate of 0.0093 ind. $\mathrm{km}^{-1}$ of gillnet set was recorded across the broader GAB region, amounting to between 14 and 33 ind. killed each breeding cycle during recent times, and between 128 and 177 over the $10 \mathrm{yr}$ since the GABMP was established in the mid-1990s. These reported bycatch levels are unlikely to be sustainable and may represent minimum estimates, because drowned individuals may drop out of the gillnet and go unobserved. A tracking program involving 9 females (5.6\% of the estimated female population) demonstrated that they spent only $27.7 \%$ of their time inside the GABMP. Four of them regularly travelled more than $180 \mathrm{~km}$ from home, or 9 times further than the southern boundary of the GABMP. These results indicate that the level of protection afforded by the GABMP to Australian sea lions residing at Bunda Cliffs is unlikely to reduce bycatch to below the levels that would reduce the risk of decline in this small population. Suggested improvements to the GABMP include a year-round closure to gillnetting, low bycatch limits and extension of the southern boundary further south. Additional regulatory mechanisms may be needed in the gillnet fishery to minimise its impact on this and other small Australian sea lion populations.
\end{abstract}

KEY WORDS: Pinniped · Australian sea lion · Endangered · Demersal gillnet · Operational interaction · Bycatch mortality $\cdot$ Foraging behaviour $\cdot$ Marine protected area

\section{INTRODUCTION}

Although commercial sealing is now banned in most regions, many pinniped populations were decimated or extirpated during the 18th, 19th and 20th centuries and are yet to recover to pre-exploitation levels (Taylor
1982, Wickens et al. 1991, Ling 1999, Harwood 2001, David \& van Sittert 2008). In more recent times, fishing effort has intensified to meet the increasing demand for fish products for human consumption, thus leading to increased incidence of direct or operational interactions between pinnipeds and commercial fisheries. As 
such, the outcomes of these interactions are now considered to be a primary contemporary threat to the conservation of many pinniped populations (Woodley \& Lavigne 1991, Wickens 1995). These events may result in individuals becoming entangled in portions of lost fishing gear, which can lead to injury, starvation and eventual death (Fowler et al. 1990, Page et al. 2004). Individuals may also become entangled in active fishing gear, thus leading to a more immediate death by drowning (Beverton 1985, Bonner 1989, Woodley \& Lavigne 1991, Wickens 1995, Shaughnessy et al. 2003).

Such incidences are known to occur in Australian waters. For example, Australian fur seals Arctocephalus pusillus doriferus enter the cod end of trawl nets to depredate caught fish off the west coast of Tasmania and sometimes drown if they fail to successfully exit the large structure (Hamer \& Goldsworthy 2006). Similarly, young Australian sea lions Neophoca cinerea depredate bait and catch from rock lobster traps in Western Australian (WA) coastal waters and sometimes drown if they become caught in the small entrance (Campbell et al. 2008b). Australian sea lions also depredate small sharks caught in demersal gillnets off South Australia (SA) and sometimes drown when they become entangled in the fine meshes (Shaughnessy et al. 2003, Page et al. 2004).

\section{Australian sea lion life history, status and vulnerability}

Unlike Australian fur seals, Australian sea lion populations have failed to recover from exploitation and recolonise their former geographic range (Warneke 1982, Gales et al. 1994, Ling 1999, Goldsworthy et al. 2003, 2009b, Shaughnessy et al. 2003, 2005, 2006, Campbell et al. 2008a, Robinson et al. 2008). Their peculiar life history may exacerbate the effect of fishery related losses. Firstly, the 17.4 to 17.8 mo long breeding cycle of the Australian sea lion has resulted in a lower level of fecundity (lifelong reproductive output) when compared with annually breeding pinnipeds, such as the conspecific New Zealand fur seal Arctocephalus forsteri (Higgins 1993, Gales \& Costa 1997). This reduces the capacity of, and rate at which, a population can recover from declines. Secondly, pronounced genetic structure is exhibited between sexually mature females from different breeding sites even in situations where geographic overlap in foraging range is extensive, thus inferring that many breeding colonies are distinct populations (Campbell et al. 2008a, Goldsworthy \& Lowther 2010). Thirdly, this situation may have arisen due to the prevalence of philopatry among sexually mature females, where individuals almost exclusively give birth and breed at their natal colony (Gales \& Costa 1997). As such, suitable but unoccupied sites adjacent to current breeding colonies are unlikely to host founder populations. Fourthly, annual estimated pup production is low at 2441 to 3610 (9300 to 17364 individuals overall) and $62 \%$ of the 76 known populations in SA and WA yield fewer than 25 pups (Gales et al. 1994, Goldsworthy et al. 2009b, Shaughnessy et al. 2011; see our Fig. 1). As such, the probability of population decline and extinction at Australian sea lion breeding sites is comparatively greater than for most other pinniped species, even if just a few individuals are lost each breeding cycle due to operational interactions with fishing gear.

\section{Extent, nature and impact of operational interactions}

The demersal shark gillnet fishery, which is managed by the Australian Fisheries Management Authority (AFMA), has operated in Australia's southern continental shelf waters since the early 1970s and has changed little since that time (Walker et al. 2005). The fishery targets gummy sharks Mustelus antarcticus and school sharks Galeorhinus galeus using monofilament polypropylene gillnetting, hung between a weighted foot rope that holds it stationary on the benthos and a floated headline that holds it upright in the water column. Waters around Australia fall into 2 zones: those belonging to each state government (inside $5.56 \mathrm{~km}$ from the coastline) and those belonging to the Australian Government (between 5.56 and $370.4 \mathrm{~km}$ from the coastline). Gillnets set inside SA (state government) waters cannot exceed $1.8 \mathrm{~km}$ in length pursuant to the SA Fisheries Management Act 2007, and those set in Australian Government waters cannot exceed $4.2 \mathrm{~km}$ in length pursuant to the Australian Government Fisheries Management Act 1991. Over $17000 \mathrm{~km}$ of gillnet were set annually between 2000 and 2008 adjacent to the SA coastline, and effort was distributed across waters shallower than $183 \mathrm{~m}$ in depth, which comprises most of the shelf area (Goldsworthy et al. 2010, Hamer et al. 2010).

Little is known about the foraging habits of Australian sea lions. An early study of free-ranging and captive Australian sea lions concluded that their diet was difficult to determine from scats, because they rarely contained identifiable hard prey remains (Gales \& Cheal 1992). However, freshly regurgitated material and the stomach contents of deceased Australian sea lions revealed that benthic dwelling fish, cephalopods, crustaceans and sharks were consumed (McIntosh et al. 2006). Recent advances in biochemical studies, such as polymerase chain reaction techniques and fatty acid 
analysis, have further confirmed the presence of benthic prey in the Australian sea lion diet (Peters et al. 2007, Baylis et al. 2009). This is reinforced by studies of dive behaviour of sexually mature females from 4 breeding sites, which indicate that foraging individuals typically spend most of their time at or near the benthos (Costa \& Gales 2003, Fowler et al. 2006, Goldsworthy et al. 2009a). Recent findings indicate that Australian sea lions forage across a large proportion of the shelf waters adjacent to SA (Goldsworthy et al. 2010, Hamer et al. 2010).

Shark gillnetters and Australian sea lions are likely to concentrate their efforts in similar locations at sea, which may result in deleterious impacts on the latter. Of all entanglements recorded at the breeding colony at Seal Bay (Kangaroo Island, SA), 55\% involved monofilament gillnets (Page et al. 2004). One demersal gillnetter estimated that 20 Australian sea lions were incidentally caught and drowned in their gillnets annually during the 1990s adjacent to the SA coastline (Shaughnessy et al. 2003). Another estimated that 12 were killed in their gear over a recent 12 mo period (Adelaide Now 2011). Other entangled individuals may initially survive, only to die later from associated injuries or starvation (Fowler 1987, Fowler et al. 1990, Page et al. 2004). A high level of shark gillnetting occurs adjacent to the Seal Bay breeding colony
(Goldsworthy et al. 2010, Hamer et al. 2010), whose population declined by $1.1 \%$ each breeding cycle between 1985 and 2002/03 (Shaughnessy et al. 2006). Interestingly, the Dangerous Reef (Spencer Gulf, SA) breeding colony increased by $0.6 \%$ each breeding cycle between 1975 and 2000/01 and then by $4.8 \%$ each breeding cycle between 2000/01 and 2006/07 (modified from Goldsworthy et al. 2007), after gillnetting was banned there (SA Government Gazette, 22 March 2001, p. 1060-1061; SA Government Gazette, 2 May 2001, p. 1703). These findings suggest that entanglement and bycatch related mortalities of Australian sea lions in demersal gillnets may be causing population declines at some breeding colonies and may be suppressing recovery at others.

\section{Mitigating impact through statutory protection}

Prior to 2000, before the proclamation of the Australian Government Environment Protection Biodiversity Conservation Act 1999 (EPBC Act), Australian fisheries were not required to report operational interactions with marine mammals. Between 2000 and 2007, only 10 seals of unidentified species were reported in the demersal gillnet fishery, suggesting that many events remained undetected or unreported

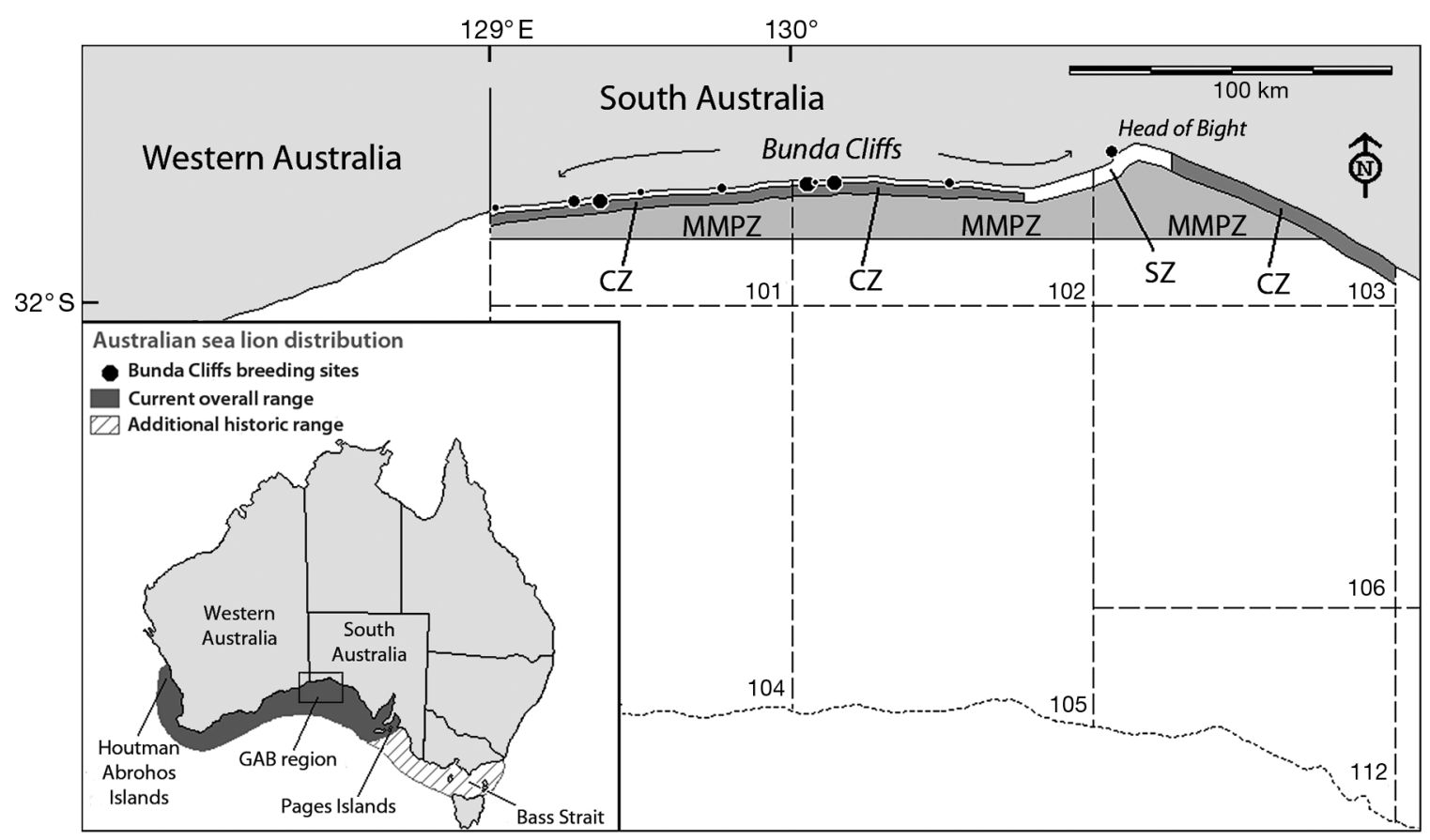

Fig. 1. Great Australian Bight Marine Park (GABMP) comprising the Sanctuary Zone (SZ), Conservation Zone (CZ) and Marine Mammal Protection Zone (MMPZ). Australian Fishery Management Authority (AFMA) fishery management areas (MFAs) 101 to 106 and 112 are also presented and were used to define the GAB region for the purposes of this study. The southern limit of the MFAs is the $183 \mathrm{~m}$ (100 fathom) depth line (short dashed line). The 10 Australian sea lion breeding sites along Bunda Cliffs and the overall range of the species in southwestern Australia are also shown 
(Hamer 2007). Growing concern about the conservation of the Australian sea lion resulted in the Australian Government Department of Environment (Department of Sustainability, Environment, Water, Population and Communities; DSEWPaC), the administrator of the EPBC Act, obtaining advice that identified entanglement and bycatch mortality in demersal gillnets as a major threatening process to the species. Consequently, the Australian sea lion was listed as vulnerable under the EPBC Act in 2005 (DEWHA 2008) and as Endangered on the International Union for the Conservation of Nature Red List in 2008 (Goldsworthy \& Gales 2008). Pursuant the EPBC Act, an ecological assessment of major commercial fisheries must be undertaken every $5 \mathrm{yr}$. Upon receipt of the ecological assessment for the demersal gillnet fishery, DSEWPaC recommended that AFMA and the fishery (1) mitigate the number of bycatch mortalities and (2) improve reporting procedures.

\section{Australian sea lions and the Great Australian Bight Marine Park}

During the early 1990s, a comprehensive survey identified 10 sites where Australian sea lions breed on a narrow boulder field at the base of Bunda Cliffs, at the head of the Great Australian Bight (GAB) in SA (Dennis \& Shaughnessy 1996, Shaughnessy et al. 2005; Fig. 1). These sites are inaccessible other than by abseiling. An estimated 161 pups were recorded from ground counts, equating to between an estimated 613 and 774 animals, or between 4.8 and $9.3 \%$ of the species (Dennis \& Shaughnessy 1996). Unfortunately, the data obtained from surveys since that time have involved remote cliff-top surveys with binoculars, suggesting that an unknown quantity of pups that shelter under the boulders would remain uncounted (South Australia Department for Environment and Heritage unpubl. data). In addition, the data are of poor quality because brown pups, moulted pups and juveniles were on occasion incorrectly classified by unskilled observers, and surveys were often incomplete and poorly timed. As such, subsequent survey data cannot be used to construct a reliable population trend. Bunda Cliffs is geographically isolated from the nearest populations to the west by about $650 \mathrm{~km}$ (Recherche Archipelago) and to the east by $300 \mathrm{~km}$ (Nuyts Archipelago). The philopatry and population genetic structure observed in other regions (Campbell et al. 2008a, Goldsworthy \& Lowther 2010) and the smaller distances that sexually mature females are known to travel from their natal colony (Fowler et al. 2007) suggest that Australian sea lions at Bunda Cliffs comprise 1 or more isolated populations.
The Great Australian Bight Marine Park (GABMP) was established in the mid-1990s pursuant to the Australian Government EPBC Act and the SA Government National Parks and Wildlife Act 1972, in part to protect Australian sea lions that reside and forage within its boundaries (Edyvane 1998, NHT 2005). The GABMP is situated in the northern reaches of the GAB waters and includes the area adjacent to the Bunda Cliffs. The GABMP straddles SA and Australian Government waters, comprising a Sanctuary Zone (SZ) and a Conservation Zone (CZ) located in SA waters and a Marine Mammal Protection Zone (MMPZ) in adjacent Australian Government waters (DEH 2005, NHT 2005). The SA and Australian Government components have their own management plan, although the GABMP is effectively managed as 1 entity under a bilateral agreement. The GABMP covers an area of approximately $21500 \mathrm{~km}^{2}$, and its boundaries are delimited by the WA border in the west $\left(129^{\circ} 00^{\prime} \mathrm{E}\right)$, Cape Adieu $\left(132^{\circ} 00^{\prime} \mathrm{E}\right)$ in the east, the SA coastline in the north and the $31^{\circ} 47^{\prime} \mathrm{S}$ latitude line in the south (Fig. 1).

Gillnet fishing is prohibited throughout the year only in a small portion of the GABMP; all of the SZ and a small part of the $\mathrm{CZ}$ in the west. The boundary of the permanently closed area extends from the low water mark at the SA-WA border, then due south $9.3 \mathrm{~km}$, then east $9.3 \mathrm{~km}$ at 9.3 from the coastline, then a further $290 \mathrm{~km}$ east at $5.6 \mathrm{~km}$ from the coastline to Cape Adieu (Edyvane 1998, NHT 2005, Gibson 2008; our Fig. 1). Gillnet fishing in the remainder of the GABMP, which extends approximately $21 \mathrm{~km}$ south of the low water mark at its farthest point, is prohibited for 6 mo of each year, between 1 May and 31 October (DEHAA 1999, DEH 2005; our Fig. 1). Despite these areas of protection and the distances they extend offshore, sexually mature females tracked from Seal Bay travelled up to approximately $75 \mathrm{~km}$ offshore (Fowler et al. 2006). Therefore, individuals residing at Bunda Cliffs may still be at risk of becoming bycatch in demersal gillnets, when foraging (1) in parts of the GABMP where fishing is permitted (i.e. the CZ and MMPZ) and (2) outside the GABMP altogether.

\section{Need and aims}

The use of MPAs to protect endangered pinniped species has proven successful in the past, by excluding fishing in areas to mitigate the chance of incidental bycatch mortality (e.g. Hawaiian monk seal Monachus schauinslandi: Lavigne 1999; Mediterranean monk seal M. monachus: Pires et al. 2008; New Zealand sea lion Phocarctos hookeri: Wilkinson et al. 2003). Given that Australian sea lion populations are likely to be vulnerable to even low levels of additional mortality 
and that shark gillnetting is permitted to occur within a substantial portion of the GABMP for half of the year, it would be useful to assess whether it provides effective protection to resident Australian sea lions. To achieve this, this study aims to determine:

(1) The level of bycatch mortality in shark gillnets specifically in the GABMP when it is open to fishing and generally across the GAB region;

(2) At-sea movements of females residing at Bunda Cliffs; and

(3) The trend in gillnet fishing effort in the GAB region over the last decade since the GABMP was established.

\section{MATERIALS AND METHODS}

Observed bycatch mortalities and fishing effort. An independent observer opportunistically accompanied 1 of 2 shark gillnet vessels fishing in the GAB region over the 2 yr study period, between January 2006 and December 2007. The GAB region was defined as the area within AFMA-derived Marine Fishery Areas (MFAs) 101 to 106 and 112 , from $129^{\circ}$ to $132^{\circ} \mathrm{E}$ and from $31^{\circ} 30^{\prime}$ to $33^{\circ} 30^{\prime} \mathrm{S}$, within which the GABMP is situated (Fig. 1). The principal task for the observer was to record the incidence and location of all fishing events and of Australian sea lions entangled and drowned in the gillnet. Where possible, age class and sex were also recorded. Observations were made during hauling by leaning outboard of the gunwale, in order to obtain an unimpeded view of the gillnet ascending through the upper several metres of the water column to the surface, then onto the net roller.

Fishery-wide gillnetting effort. Partially summarized shark gillnet fishing effort data derived from fishery logbooks were obtained from AFMA. Since 1 July 2007, it has been mandatory for all vessels in the shark gillnet fishery to record the exact location of fishing events by degrees and minutes of latitude and longitude. Prior to this, fishers were only required to record the number of the MFA they fished in. MFAs conform to degrees of latitude and longitude, thus measuring 92 to $95 \mathrm{~km}$ along parallels of latitude at $31^{\circ}$ to $34^{\circ} \mathrm{S}$ and about $111 \mathrm{~km}$ along meridians of longitude, or between $10212 \mathrm{~km}^{2}$ and $10545 \mathrm{~km}^{2}$ in area, respectively. The decision was made to use MFA-scale effort data, because they were consistently collected over the study period, whereas point location data were not.

The effort data were used to calculate the number of kilometres of gillnet set in each year and within each MFA and within each of the 3 areas within the GABMP, namely the SZ, CZ and MMPZ. It was assumed, based on discussions with fishers, that maximum permitted net lengths were used, i.e. $1.8 \mathrm{~km}$ in
SA waters and $4.2 \mathrm{~km}$ in Australian Government waters. Given that it was not possible to determine the exact location of fishing events when recorded at the MFA scale, effort in MFAs intersected by the SA-Australian Government boundary and by the GABMP boundaries, namely 101, 102 and 103, was apportioned according to area.

Bycatch rates and estimates. The number of observed bycatch mortalities was recorded and the bycatch rate calculated by dividing this figure by the number of kilometres of gillnet observed hauled. This was done for 5 zones of interest: (1) SA waters in the GABMP (SZ and CZ), (2) Australian Government waters in the GABMP (MMPZ), (3) all of the waters in the GABMP (SZ, CZ and MMPZ combined), (4) the remaining waters of the $\mathrm{GAB}$ region as defined in this study (to the south of the GABMP) and (5) the entire GAB region. Estimates of bycatch were extrapolated for each of the 5 regions, by multiplying the 5 bycatch rates by the overall number of kilometres of gillnet set in each zone, as reported in AFMA fishery logbooks. This was done over 3 time periods: (1) the 2 yr study period, (2) a 17.6 mo (nominal) breeding cycle and (3) a 10 yr period that approximated the time from when the GABMP was proclaimed to the conclusion of this study period. In the absence of data, spatial and temporal distribution of Australian sea lion bycatch and shark gillnetting effort across the region was assumed to be even. Estimates of bycatch were rounded up to the nearest whole number to reflect whole individuals. Due to observer effort being less than 100\%, the approximate 95\% confidence interval (CI) for each bycatch mortality estimate was calculated using the standard error for each estimate (SEE) technique:

$$
\mathrm{SEE}=\sqrt{\left(1-\frac{\text { observer effort }}{\text { fishing effort }}\right)} \times \text { mortality estimate }
$$

where variance is scaled by 1 minus the sample fraction (i.e. the finite population correction) and assuming that each estimate was based on a Poisson distribution (Cochrane 1977, Zar 1999). The lower and upper confidence bounds (CBs) of the bycatch estimates were then calculated by subtraction and addition, respectively, of 2 times the SEE from the mortality estimate (Cochrane 1977, Zar 1999).

At-sea movements of sexually mature females. Satellite-linked platform transmission terminals (PTTs; KiwiSat 101, Sirtrack) were attached to sexually mature female Australian sea lions at the 2 largest breeding sites at Bunda Cliffs, referred to in this study as the western site $\left(31^{\circ} 38^{\prime} 35^{\prime \prime} \mathrm{S}, 129^{\circ} 22^{\prime} 59^{\prime \prime} \mathrm{E}\right)$ and the central site $\left(31^{\circ} 35^{\prime} 20^{\prime \prime} \mathrm{S}, 130^{\circ} 03^{\prime} \mathrm{E}\right)$. The estimated number of pups counted at these 2 sites in 1994 was 38 and 43, respectively (Dennis \& Shaughnessy 1996). 
Lactating females were chosen, because they produce the next generation and were identified by the presence of a suckling pup prior to capture, or by the presence of milk upon capture.

Four PTTs were deployed at the western site after the end of a breeding season in April 2006, and 5 PTTs were deployed at the central colony during the following breeding season in May 2007. Access to the narrow and undulating terraces at the base of Bunda Cliffs, where the breeding sites were located, was hindered by a large boulder field and $100 \mathrm{~m}$ high vertical cliffs. The only means of access was via the cliffs, which required the use of specialised abseiling and climbing equipment. A purpose-built, conical net was used to capture and immobilise target animals. Anaesthesia was facilitated with $100 \%$ isoflorane (Isoflo $^{\mathrm{TM}}$, Veterinary Companies of Australia), delivered via a gas anaesthesia apparatus fitted with a Cyprane Tec III vaporiser (Advanced Anaesthetic Specialists). The degree of induction was controlled by adjusting the concentration and delivery rate of Isoflo ${ }^{\mathrm{TM}}$, based on vital signs such as heart rate, rate and depth of breathing, degree of openness of the airway, gum colour, capillary return, and eye and tail reflexes. The PTTs were positioned alongside the mid-dorsal line, $10 \mathrm{~cm}$ posterior of the fore-flipper pits. Attachment was made to the guard hairs using Araldite ${ }^{\circledR} 2107$ (Huntsman Advanced Materials).

Location data were obtained from Service Argos. Class 3, 2, 1 and 0 positions were used in the analysis, while A, $\mathrm{B}$ and $\mathrm{Z}$ class positions were omitted due to their inaccuracy (Sterling \& Ream 2004, Costa et al. 2010). With the use of a saltwater conductivity switch, each PTT paused transmission of location data when the tracked individual hauled out for longer than $1 \mathrm{~h}$ and immediately recommenced upon re-entering the water, thus allowing individual foraging trips to be identified prior to analysis. The removal of the data in between foraging trips eliminated a near-shore bias of foraging time in areas adjacent to the western and central sites.

The remaining location data were used to establish the spatial distribution of foraging effort, as a value of time, by redistributing the effort into $1 \mathrm{~km}^{2}$ grid cells, using $\mathrm{R}$ (version 2.3.0, R Foundation for Statistical Computing) and the specifically written script trip (version 1.1, M.D. Sumner, University of Tasmania). Erroneous locations were identified by trip as those that exceeded a maximum possible pinniped linear swim speed of $2 \mathrm{~m} \mathrm{~s}^{-1}$ (Kuhn et al. 2009) from either of the 2 adjacent locations and were subsequently redistributed closer to those 2 adjacent locations. The average linear swim speed between 2 recorded locations was then used to assign each 15 min parcel of time along that line to the appropriate grid cell, thus allowing the time spent in each cell to be calculated.
Location fixes at the beginning and end of each foraging trip were often inaccurate or absent, possibly due to Bunda Cliffs hindering satellite communication. As such, the exact time a tracked animal left or returned to the breeding site was often unclear. To address this, exact coordinates for the breeding site were manually included in the data set as the first and last position for each manually identified foraging trip. The script trip was used to determine the additional time taken to travel between the breeding site and the first or last recorded location for each trip, using the maximum linear swim speed of $2 \mathrm{~m} \mathrm{~s}^{-1}$.

The spatial distribution of foraging effort, as time, was calculated for the 5 regions in the $\mathrm{GAB}$ and GABMP, as described above. To accurately reflect the contribution of foraging effort by each of the 2 breeding sites, resulting values for each grid cell were weighted according to the contribution of each tracked animal to the overall tracking time calculated for the breeding site it originated from and of each breeding site to the overall tracking time calculated for both breeding sites. The time spent in each grid cell or area was plotted using MapInfo Professional ${ }^{\circledR}$ and Vertical Mapper ${ }^{\circledR}$ (versions 8.0 and 2.5 respectively, MapInfo Corporation).

The mean maximum distance and mean direction from the breeding site were also calculated for each tracked animal. Mean direction was established by calculating the bearing from the breeding site to the maximum distance travelled during each foraging trip. Maximum distances less than $5 \mathrm{~km}$ from the breeding site were not included, to minimise directional errors associated with data obtained from Service Argos.

\section{RESULTS}

\section{Observed bycatch mortalities and fishing effort}

Four Australian sea lion bycatch mortalities were observed during the study period (Table 1, Fig. 2). All dropped out of the gillnet and sank when it was hauled above the waterline at the end of the fishing event. Due to the distinctive pelage colouration and size of the individuals, the observer positively identified 2 as sexually mature females, one as a bull and the other as a juvenile of unknown sex. Three, excluding the bull, were caught within the GABMP, with 1 caught in the CZ just outside the AFMA closure approximately $3.8 \mathrm{~km}$ offshore and the other 2 caught in the MMPZ just outside the $\mathrm{CZ}$. The bull was caught approximately $46 \mathrm{~km}$ south of the GABMP. Over the $2 \mathrm{yr}$ study period, a total of $431.4 \mathrm{~km}$ of gillnet (113 fishing events) was observed hauled in the GAB region, of which $145.8 \mathrm{~km}$ (45 fishing events) occurred in the GABMP (Table 1, Fig. 2). 
Table 1. Neophoca cinerea. Summary of Australian sea lion bycatch in demersal shark gillnets in the Great Australian Bight Marine Park (GABMP) and also across the entire GAB region as defined in this study. Bycatch was estimated for (1) the 2 yr period during which the study was conducted (January 2006 to December 2007), (2) a recent 17.6 mo breeding cycle in which the bycatch estimate was a fraction of the 24 mo study period (i.e. 17.6/24 = 0.7333) and (3) a 10 yr period (January 1998 to December 2007) approximating the time from when the GABMP was proclaimed to the time when the study was concluded. Mortality rate was calculated as the number of observed mortalities divided by the number of $\mathrm{km}$ of gillnet observed hauled. The mortality estimate was calculated as the mortality rate multiplied by fishing effort, with standard error of the estimate (and lower and upper confidence bounds in parentheses) rounded up to nearest whole number or individual. SA: South Australia; Aus Govt.: Australian Government, SZ: Sanctuary Zone, CZ: Conservation Zone; MMPZ: Marine Mammal Protection Zone. The GABMP combines the area of the SZ, CZ and MMPZ, and the remaining GAB waters encompass the area across the remainder of the GAB region, as defined in this study, to the south of the GABMP

\begin{tabular}{|c|c|c|c|c|c|c|c|c|}
\hline \multirow{2}{*}{$\begin{array}{l}\text { Management } \\
\text { zone }\end{array}$} & \multicolumn{3}{|c|}{$\begin{array}{l}\text { Observer data summary } \\
\text { Jan } 2006 \text { - Dec } 2007\end{array}$} & \multicolumn{2}{|c|}{$\overline{\text { Jan } 2006-\text { Dec } 2007}$} & \multirow{2}{*}{$\begin{array}{l}\text { - Bycatch estimates } \\
\text { Recent } \\
\text { mortality } \\
\text { estimate }\end{array}$} & \multicolumn{2}{|c|}{ Jan 1998 - Dec 2007} \\
\hline & $\begin{array}{l}\text { Observer } \\
\text { effort }(\mathrm{km})\end{array}$ & $\begin{array}{c}\text { Mortalities } \\
\text { observed }\end{array}$ & $\begin{array}{l}\text { Mortality } \\
\text { rate }\end{array}$ & $\begin{array}{l}\text { Fishing } \\
\text { effort }(\mathrm{km})\end{array}$ & $\begin{array}{l}\text { Mortality } \\
\text { estimate }\end{array}$ & & $\begin{array}{l}\text { Fishing } \\
\text { effort }(\mathrm{km})\end{array}$ & $\begin{array}{l}\text { Mortality } \\
\text { estimate }\end{array}$ \\
\hline $\begin{array}{l}\text { SZ and CZ } \\
\text { (SA waters) }\end{array}$ & 32.4 & 1 & 0.0308 & 89.7 & $\begin{array}{c}3 \pm 1.4 \\
(1,6)\end{array}$ & $\begin{array}{c}3 \pm 1.5 \\
(1,6)\end{array}$ & 305.5 & $\begin{array}{l}9 \pm 2.8 \\
(4,15)\end{array}$ \\
\hline $\begin{array}{l}\text { MMPZ } \\
\text { (Aus. Govt. waters) }\end{array}$ & 113.4 & 2 & 0.0176 & 448.4 & $\begin{array}{l}8 \pm 2.4 \\
(4,13)\end{array}$ & $\begin{array}{l}6 \pm 2.2 \\
(2,11)\end{array}$ & 1528.2 & $\begin{array}{l}27 \pm 5.0 \\
(18,37)\end{array}$ \\
\hline $\begin{array}{l}\text { GABMP } \\
\text { (SZ, CZ and MMPZ) }\end{array}$ & 145.8 & 3 & 0.0206 & 538.1 & $\begin{array}{c}11 \pm 2.8 \\
(6,17)\end{array}$ & $\begin{array}{l}9 \pm 2.7 \\
(4,15)\end{array}$ & 1833.7 & $\begin{array}{l}38 \pm 5.9 \\
(27,50)\end{array}$ \\
\hline $\begin{array}{l}\text { Remaining GAB } \\
\text { waters }\end{array}$ & 285.6 & 1 & 0.0035 & 2754.7 & $\begin{array}{c}10 \pm 3.0 \\
(5,16)\end{array}$ & $\begin{array}{l}8 \pm 2.7 \\
(3,14)\end{array}$ & 14541.3 & $\begin{array}{l}51 \pm 7.1 \\
(37,66)\end{array}$ \\
\hline Entire GAB region & 431.4 & 4 & 0.0093 & 3292.8 & $\begin{array}{l}31 \pm 5.2 \\
(21,42)\end{array}$ & $\begin{array}{l}23 \pm 4.6 \\
(14,33)\end{array}$ & 16375.0 & $\begin{array}{l}152 \pm 12.2 \\
(128,177)\end{array}$ \\
\hline
\end{tabular}

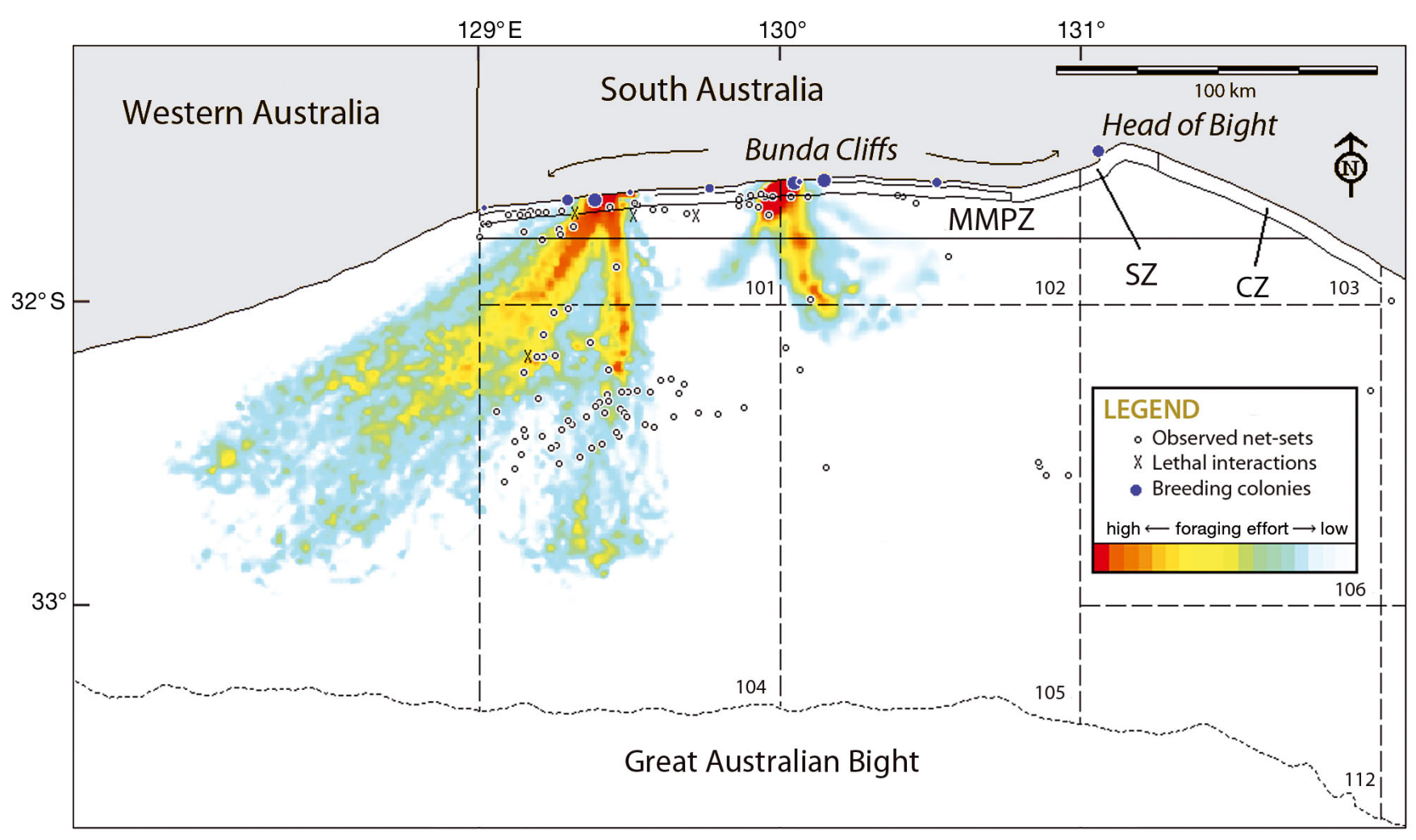

Fig. 2. Neophoca cinerea. Summary of at-sea movements of 9 sexually mature female Australian sea lions tracked from 2 sites at Bunda Cliffs, South Australia. The location of observed gillnet sets and bycatch mortalities are also presented. Abbreviations as in Fig. 1 


\section{Fishery-wide gillnetting effort}

Between January 1998 and December 2007, $197689 \mathrm{~km}$ of gillnet was set in SA, of which 16375 $\mathrm{km}$ was set in the GAB region (AFMA unpubl. data). During the 2 yr study period, $3292.8 \mathrm{~km}$ of gillnet was set in the GAB region, of which $538.1 \mathrm{~km}$ occurred in the GABMP and $2754.7 \mathrm{~km}$ occurred to the south, across the remainder of the GAB. Fishing effort in the $\mathrm{GAB}$ region declined by $73.8 \%$ between 1998 and 2002 (from 3001 to $786 \mathrm{~km}$ ), then increased by $403.9 \%$ between 2002 and 2007 (from 786 to 3175 km; Fig. 3). The decline coincided with target stock depletion in the late 1990s and the introduction of quota in 2001, while the increase coincided with stock recovery and renewed interest by demersal shark gillnet fishers in the GAB region (Fig. 3). Given that fishers were only required to record fishing effort at the MFA scale prior to 1 July 2007 and voluntarily by degrees and minutes thereafter, the spatial distribution of fishing effort for most of the data collected during the study period was very coarse. As such, it was not possible to accurately measure changes in geographic distribution over time.

\section{Bycatch rates and estimates}

Based on the observed bycatch and fishery data, the Australian sea lion bycatch mortality rate for the study period was 0.0093 ind $\mathrm{km}^{-1}$ of gillnet set across the entire $\mathrm{GAB}$ region, 0.0206 ind. $\mathrm{km}^{-1}$ in the GABMP and 0.0035 ind $\mathrm{km}^{-1}$ to the south, across the remainder of the GAB (Table 1). In contrast, the mortality rate calculated from AFMA logbooks for all SA shelf waters for

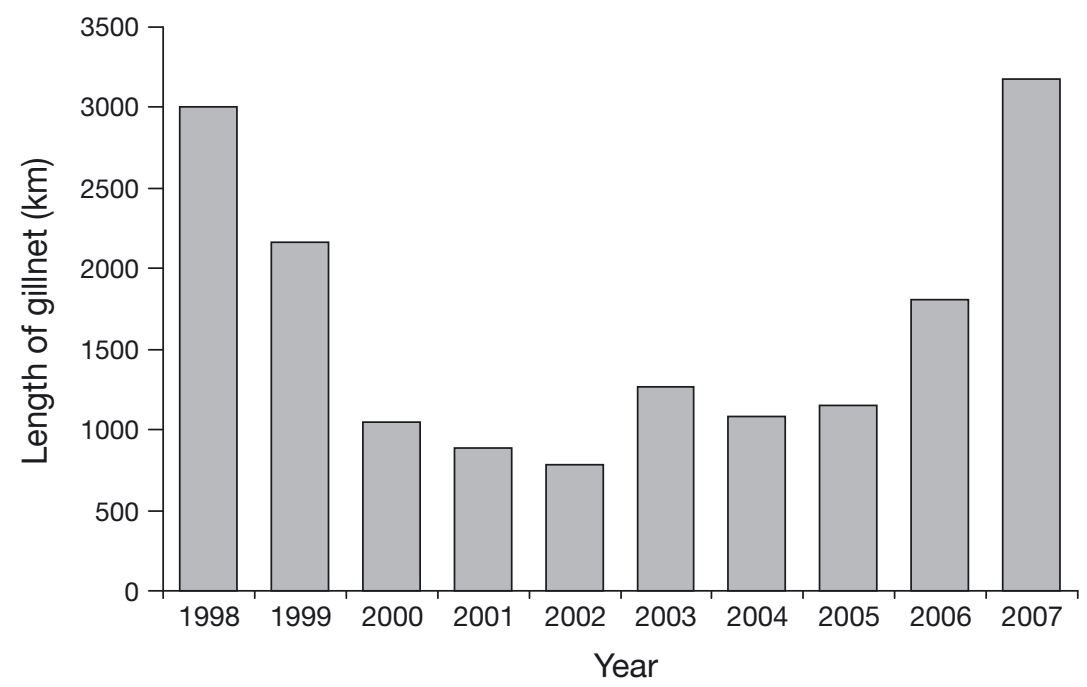

Fig. 3. Summary of gillnet fishing effort $(\mathrm{km})$ by year in the Great Australian Bight region, based on AFMA logbook data the period October 1999 to January 2006 (i.e. from when the EPBC Act took effect to the beginning of this study) was $4.9 \times 10^{-5}$ ind. $\mathrm{km}^{-1}$ of gillnet set, based on 7 reported mortalities and $143752 \mathrm{~km}$ of gillnet set (AFMA unpubl. data). Comparison of rates derived from observer data and AFMA data suggest that those reported in this study were 190, 420 and 71 times higher, respectively.

During the study period, the observer program monitored $13.1 \%$ of fishing effort across the GAB region, $27.1 \%$ in the GABMP and $10.4 \%$ to the south of the GABMP in the remainder of the GAB (Table 1). An extrapolated estimate of Australian sea lion bycatch mortality based on all gillnet fishing activity within the GABMP during the most recent breeding cycle was $9 \pm$ 2.7 (SEE; CBs: 4,15) individuals. Extrapolated estimates of bycatch mortality across the broader GAB region, as defined in this study, amounted to $23 \pm 4.6$ (CBs: 14,33) killed there during the most recent breeding cycle, $31 \pm 5.2$ (CBs: 21,42) during the $2 \mathrm{yr}$ study period and $152 \pm 12.2$ (CBs: 128,177) during the $10 \mathrm{yr}$ period since the GABMP was proclaimed.

\section{At-sea movements of sexually mature females}

The 4 Australian sea lions tracked from the western site were monitored for $971 \mathrm{~d}$ (mean $\pm \mathrm{SD}=243 \pm 37 \mathrm{~d}$ ) and the 5 tracked from the central site were monitored for $215 \mathrm{~d}$ (mean $=43 \pm 13 \mathrm{~d}$; Table 2). These 9 individuals constituted $5.6 \%$ of sexually mature females, based on the 1994 estimate of 161 pups. The mean distance travelled from the western site was $83 \pm 35 \mathrm{~km}$ (mean of maximum distances travelled: $180 \mathrm{~km}$ ) and from the central site was $30 \pm 18 \mathrm{~km}$ (mean maximum: 69 km; Table 2, Fig. 2). The mean and mean maximum distances travelled from the western site were 2.8 and 2.6 times greater than from the central site, respectively. Of all foraging trips, $96 \pm 17 \%$ of those recorded from the western site and $67 \pm 12 \%$ of those recorded from the central site went beyond the southern boundary of the GABMP. Individuals tracked from the western site travelled in a southwesterly direction (mean bearing $=205 \pm$ $26^{\circ}$ ), while individuals from the central site travelled south (mean bearing $=187 \pm 39^{\circ}$ ). There was no spatial overlap between animals tracked from the western and central sites, although 8 of the 9 animals swam distances farther from their natal colony than the $63 \mathrm{~km}$ separating the 2 sites. 
Table 2. Neophoca cinerea. Summary of tracking data for 9 sexually mature female Australian sea lions from 2 sites at Bunda Cliffs, South Australia. The satellite transmitter deployment period is shown in number of days. The distance (and direction) travelled was calculated as the distance (and direction) of each location fix from the deployment site (either B8 or B5). Mean distances and directions were calculated as the mean of all trips from the deployment site

\begin{tabular}{|c|c|c|c|c|c|}
\hline \multicolumn{3}{|c|}{ Deployment summary } & \multirow{2}{*}{\multicolumn{2}{|c|}{$\begin{array}{c}\text { Distance travelled } \\
(\mathrm{km})\end{array}$}} & \multirow{3}{*}{$\begin{array}{c}\text { Direction travelled } \\
\text { (deg.) } \\
\text { Mean } \pm \text { SD }\end{array}$} \\
\hline Seal ID & Observed & No. days & & & \\
\hline & & & Mean $\pm \mathrm{SD}$ & Max & \\
\hline \multicolumn{6}{|c|}{ Western site (B8): 2006} \\
\hline 55933 & With pup & 189 & $93 \pm 41$ & 187 & $228 \pm 15$ \\
\hline 55962 & Lactating & 273 & $65 \pm 29$ & 181 & $211 \pm 22$ \\
\hline 55973 & Suckling & 252 & $99 \pm 29$ & 193 & $205 \pm 37$ \\
\hline \multirow[t]{3}{*}{55975} & Lactating & 257 & $74 \pm 40$ & 158 & $174 \pm 29$ \\
\hline & Mean & 243 & $83 \pm 35$ & 180 & $205 \pm 26$ \\
\hline & Total & 971 & & & \\
\hline \multicolumn{6}{|c|}{ Central site (B5): 2007} \\
\hline 55938 & Suckling & 49 & $26 \pm 16$ & 68 & $192 \pm 36$ \\
\hline 55940 & Lactating & 33 & $39 \pm 16$ & 63 & $168 \pm 22$ \\
\hline 55964 & With pup & 36 & $16 \pm 14$ & 53 & $210 \pm 44$ \\
\hline 55974 & Lactating & 34 & $25 \pm 20$ & 66 & $172 \pm 53$ \\
\hline \multirow[t]{5}{*}{55978} & Suckling & 63 & $44 \pm 26$ & 84 & $192 \pm 42$ \\
\hline & Mean & 43 & $30 \pm 30$ & 69 & $187 \pm 39$ \\
\hline & Total & 215 & & & \\
\hline & Overall mean & 132 & $53 \pm 27$ & 117 & $195 \pm 33$ \\
\hline & Overall total & 1186 & & & \\
\hline
\end{tabular}

Table 3. Neophoca cinerea. Summary of the of spatial utilisation by 9 sexually mature female Australian sea lions tracked from 2 sites at Bunda Cliffs, South Australia, shown by management zone and percentage. Abbreviations and definitions of management zones as in Table 1; Western Australia (WA) includes all waters to the west of the GABMP, adjacent to WA coastline

\begin{tabular}{|lccc|}
\hline \multirow{2}{*}{$\begin{array}{l}\text { Management } \\
\text { zone }\end{array}$} & \multicolumn{3}{c|}{ Time spent in each zone (\%) } \\
& Western site & Central site & Combined \\
\hline SZ \& CZ (SA waters) & 14.4 & 27.3 & 16.0 \\
MMPZ (Comm. waters) & 9.7 & 26.1 & 11.7 \\
GABMP (SZ, CZ \& MMPZ) & 24.1 & 53.4 & 27.7 \\
Remaining GAB waters & 45.4 & 46.6 & 45.5 \\
WA & 30.5 & 0.0 & 26.8 \\
Total (\%) & 100.0 & 100.0 & 100.0 \\
Total (h) & 16658.0 & 2331.6 & 18989.6 \\
\hline
\end{tabular}

Individuals tracked from the western site spent $24.1 \%$ of their time at sea within the GABMP $(14.4 \%$ in the SZ and CZ and 9.7\% in the MMPZ) and 75.9\% of their time in adjacent Australian Government waters $(45.4 \%$ off SA and $30.5 \%$ off WA; Table 3, Fig. 2). Four of the 5 animals from the western site were tracked for 7 to $9 \mathrm{mo}$, during which time little changed in the geographic distribution of consecutive foraging trips. Individuals tracked from the central site spent $53.4 \%$ of their time at sea in the GABMP (27.3\% in the SZ and CZ and 26.1\% in the MMPZ) and $46.6 \%$ of their time in adjacent Australian Government waters off SA (Table 3, Fig. 2).

\section{DISCUSSION}

Prior to this study, only 1 other has attempted to assess the effectiveness of spatial management arrangements for protecting Australian sea lions. In WA, bycatch of pups and juveniles in rock lobster pots was mitigated by mandating the use of sea lion exclusion devices (SLEDs) within in-shore waters around breeding colonies (Campbell et al. 2008b). However, our study is the first to specifically assess the effectiveness of an MPA that was designed in part to conserve Australian sea lions. This task proved logistically challenging, because access to the colonies at the base of Bunda Cliffs was dangerous (Dennis \& Shaughnessy 1996), thus minimising the number of opportunities to deploy PTTs. Access to vessels also required extensive negotiations (Hamer et al. 2009), because fishers were fearful that interactions with Australian sea lions might jeopardise their future fishing activities, particularly within the GABMP.

During the observer program, 4 Australian sea lion mortalities occurred from $431.4 \mathrm{~km}$ of observed set gillnet, equating to 0.0093 mortalities $\mathrm{km}^{-1}$. This amounted to between 14 and 33 mortalities during the most recent breeding cycle, between 21 and 42 during the 2 yr study and between 128 and 177 during the $10 \mathrm{yr}$ period since the GABMP was proclaimed. It should be noted that confidence bounds reported over the longer time scale could be unreliable due to the small sample size, although the estimate is likely to be within the upper and lower limit of the range. This level of bycatch may have negative implications for the conservation of Australian sea lions and has provided encouragement to explore the benefits of a quantitative risk assessment, with a recent study modelling the impacts of Australian sea lion bycatch in gillnets across all breeding populations in SA (Goldsworthy et al. 2010). However, the results of that study were plagued by a high degree of uncertainty in the data available for Australian sea lions (e.g. life history characteristics and population status) and the fishery (e.g. effort and bycatch incidence), both of which resulted in the need to incorporate assumptions that may have affected the results. Therefore, the 
quantitative approach to determining the impact of the gillnet fishery on Australian sea lions across SA shelf waters would benefit from the use of more accurate fishing effort and bycatch data from the former and foraging effort data for the latter.

Despite these challenges in a relatively data-poor environment, some lessons can be learned from a first principles approach. If it is assumed that there are twice as many sexually mature females in the Bunda Cliffs population as the 161 pups estimated in 1994 (Dennis \& Shaughnessy 1996) and the intrinsic growth rate of $4.8 \%$ during each breeding cycle reported at Dangerous Reef is realistic (Goldsworthy et al. 2007), then only 13 sexually mature females need be removed in each breeding cycle before population decline becomes imminent. If it is then assumed that half of the 14 to 33 bycatch mortalities (say 7 to 17 ) estimated in the $\mathrm{GAB}$ region during recent breeding cycles are sexually mature females, based on the bycatch data obtained, then the Bunda Cliffs population may be at risk of decline.

The potential risk of population decline highlighted here may be understated, because Australian sea lions that have drowned may drop out of the gillnet below the surface and out of sight of the observer, or those that have become entangled may break free and escape with gillnet material caught around their neck. This situation arises because gillnet meshes are designed to break at 300 to 400 Newtons to facilitate the release of larger, unwanted sharks (Murphy \& Richardson 2002). Adult Australian sea lions are of comparable size, and in cases where death occurs, the struggle is likely to have been short due to ensuing panic and associated rapid oxygen depletion. The extent of subsequent entanglement is likely to be minimal, thus increasing the chance that drowned individuals will drop out of the gillnet. It became evident during this study that fishers assumed all entangled animals would be landed on the deck. The fact that this was not the case highlights the need to view observed and reported bycatch as a fraction of the overall numbers drowning in gillnets. It also reinforces the need for fishers and observers to focus their monitoring efforts over the side of the vessel where the gillnet is being hauled rather than on the deck, to increase the chance of detecting a greater proportion of those drowned individuals that at least make it to the surface before dropping out.

Three of the 4 recorded bycatch mortalities occurred within the GABMP, because fishing (thus monitoring) took place close to Bunda Cliffs during the open period. Had the GABMP been closed to fishing, the level of bycatch may have been more than halved during recent breeding cycles. This study raises concerns about the effectiveness of the GABMP under its cur- rent management arrangements. Rarely have MPAs been proclaimed for a pinniped species (Pires et al. 2008), although their purpose should be to exclude any human activity that deleteriously impacts or threatens the species to be conserved (Hooker \& Gerber 2004). It seems incongruous to allow commercial-scale fishing activities, particularly of the nature described in this study, to occur within the GABMP.

The female Australian sea lions tracked from the western and central sites of the Bunda Cliffs, while behaving quite differently, expended a considerable proportion of their foraging effort outside the GABMP (half to three-quarters of their time at sea, two-thirds to most of their foraging trips and 3 to 9 times further than the southern boundary). This is principally because the southern boundary of the GABMP is at most only $21 \mathrm{~km}$ south of the coastline. Prior to this study, the only report of maximum distances attained by sexually mature females during foraging trips was about $75 \mathrm{~km}$ from Seal Bay (Fowler et al. 2007). Despite this threatening process being permitted within the GABMP for half of the year, the distances travelled by Australian sea lions residing at Bunda Cliffs suggest that they are exposed to the risk of drowning in gillnets year round.

The differences in the at-sea distribution of effort of Australian sea lions from different breeding sites is likely to be linked with the patchy distribution of their benthic prey, which is governed by the heterogeneous structure of the benthos along Australia's southern coastline (Edgar 2008). Unlike pelagic foragers that track highly mobile pelagic prey in a 3-dimensional space (Baylis et al. 2008), Australian sea lions are likely to regularly visit the same structures on the sea floor if the returns are favourable. This study did not allow longer-term, inter-seasonal foraging strategies to be revealed, and thus should be viewed as a snapshot in time. Nonetheless, preliminary investigations of the data obtained for 4 of the animals that were tracked for 7 to 9 mo indicated that little changed in their at-sea behaviour between successive foraging trips, suggesting that prey availability in the benthic environment is relatively stable and predictable (Edgar 2008).

It should be recognised that fishing effort during this study was much lower than between the 1970s and mid-1990s. The late 1990s marked the end of a considerable decline in the activities of the fishery, mainly due to the collapse of the school shark stock (Walker et al. 2005). Therefore, the much higher level of fishing effort in the GAB region during the previous 2 decades would have resulted in much higher estimates of bycatch mortality of Australian sea lions, suggesting that the estimates calculated in this study may understate the longer-term impact of the fishery on Australian sea lions in the GAB region. 


\section{SUMMARY AND RECOMMENDATIONS}

This study revealed that Australian sea lions residing at Bunda Cliffs are at risk of drowning in shark gillnets that are set within the GABMP for half of the year and across the GAB region throughout the year. These management arrangements seem contradictory to the purpose and goals of an MPA (Hooker \& Gerber 2004). The Australian Government management plan for the GABMP states that it aims to ensure the 'preservation of the area in its natural condition' and to 'protect....habitat for the Australian sea lion', and also acknowledges that the species is listed as vulnerable under the EPBC Act (DEH 2005). The SA management plan uses stronger language, specifically aiming to 'protect and assist in the recovery of....Australian sea lions' (DEHAA 1999).

Despite these differences between the 2 management plans, together they continue to permit the use of gillnets across most of the GABMP for half of the year; thus, the likelihood of bycatch mortalities occurring remains high. Highlighting this finding is especially important, because gillnetting was formally identified as a key threat to the conservation of Australian sea lions in 2005 (DEWHA 2008). The findings of this study may be timely, because the current Australian Government plan expires in 2012 although the SA plan can be reviewed at any time in light of new information. As such, GABMP managers are encouraged to amend the language used in the 2 plans to more cohesively protect Australian sea lions residing in the GABMP.

The Australian sea lions tracked in this study revealed that important foraging grounds may also exist outside the GABMP. The only previously published study of the at-sea distribution of effort indicated that sexually mature females foraged up to $75 \mathrm{~km}$ from home (Fowler et al. 2007). However, animals tracked from Bunda Cliffs foraged 2.5 times that distance $(180 \mathrm{~km})$ and almost 9 times farther south than the southern border of the GABMP. A similar situation existed for Hector's dolphins Cephalorhynchus hectori hectori in the Banks Peninsula Marine Mammal Sanctuary (New Zealand), where the distribution of demersal gillnets and of bycatch indicated that the seaward boundary of the sanctuary would need to extend a further $28 \mathrm{~km}$ in order to reduce bycatch rates to acceptable levels (Slooten et al. 2006). Using this principle, GABMP mangers should consider extending the southern boundary to more accurately cover the areas utilised by foraging Australian sea lions from Bunda Cliffs, thus more effectively protecting the population from the effects of bycatch mortality.

All of the Australian sea lions reported drowned actually dropped out of the gillnet as they were hauled above the surface, before they could be landed on the deck of the vessel. However, fishers and fishery observers typically concentrate their attention on the deck, in the expectation that all organisms caught in the gillnet will be landed there. This false expectation may explain why the bycatch rates recorded in this study were up to 3 orders of magnitude (i.e. $100 \mathrm{~s}$ of times) higher than those recorded in AFMA log books. The propensity for drowned animals to drop out of the gillnet at the surface due to the minimal extent of their physical entanglement suggests that an unknown proportion may become caught, drown and then drop out well below the surface, before they can be detected. Others may escape only to die later from injuries caused by gear lodged around their neck (Shaughnessy et al. 2003, Page et al. 2004). This study is the first to reveal that the impact of drowned animals, including those that drop out of the gillnet and those that escape with a gillnet entanglement, may be extensive, both in the GAB region and across the range of the species. This situation should be considered when reviewing the current access arrangements and boundary placement, before the effectiveness of the GABMP in protecting Australian sea lions can be assured.

If fishing is to persist in and adjacent to the GABMP, despite the evidence presented here, then imposing conservative bycatch limits to prevent population decline would be necessary. The concept of potential biological removal (PBR) limits was first introduced in the United States Marine Mammal Protection Act in 1994 and was designed to prevent population decline in situations where humaninduced mortalities occurred (Wade 1998). The PBR approach was also used to set bycatch limits for the endangered New Zealand sea lion in the Auckland Island squid trawl fishery and resulted in 3 statutory closures and 2 voluntary withdrawals between 1995 and 2000 (Wilkinson et al. 2003). As indicated earlier, the loss of 13 or more individuals as bycatch in each breeding cycle is likely to lead to a population decline at Bunda Cliffs. In order to ensure that the necessarily low bycatch limits are adhered to, high levels of observer coverage may be needed (Lopez et al. 2003, Hamer et al. 2008, Jaaman et al. 2009). In simplistic terms, if the PBR is 7 female Australian sea lions and the level of observer coverage is $50 \%$, then there is a chance that as many as 14 females may be caught before fishing activities cease. Under such a scenario, the Bunda Cliffs population would still be at risk of decline, even though bycatch limits and an observer program were in place. This suggests that either the trigger limits should be reduced in recognition of the uncertainty, or that the level of 
observer coverage should be increased to reduce the uncertainty.

Based on the findings of this study, the following suggestions for improving the current management arrangements of the GABMP and the conservation outlook for resident Australian sea lions are made:

(1) Year-round exclusion of gillnetting in all zones;

(2) Low bycatch limits;

(3) Extension of the southern boundary further south.

This study has demonstrated that much can be done to improve the effectiveness of the GABMP in protecting Australian sea lions. However, shark gillnetting occurs extensively across the continental shelf adjacent to the SA coastline in both SA and adjacent Australian Government waters, where many other Australian sea lion breeding colonies are located (Hamer et al. 2007, 2010, Goldsworthy et al. 2010). As such, the conservation of Australian sea lions in the GAB and other regions may benefit from the reduction of bycatch in shark gillnets through carefully placed closures and more stringent monitoring of gillnetting. Population monitoring of key Australian sea lion breeding sites may also be necessary in order to ascertain the long-term benefits of the various initiatives taken by the responsible government agencies. Nonetheless, it will be both necessary and challenging to improve relationships that facilitate appropriate and timely outcomes that benefit Australian sea lion populations in the GABMP and throughout their range, while allowing shark fishing to continue in an economically viable manner.

Acknowledgements. We sincerely thank the owners of The Fish Factory Pty. Ltd. (L., K. and P. Toumazos) and their skippers (M. Larsson FV 'Lutarna' and G. McDonald FV 'Jean Bryant') for access to vessels and enthusiastic support during the observer program; A. Ivey (South Australian Research and Development Institute, SARDI) for assistance with collecting observer data; D. Frazer (Environmental Biodiversity Services, EBS) and B. Page (SARDI) for assistance with sea lion captures; P. Codrington, P. Bache and D. Skinner (State Emergency Service, SES) for facilitating vertical access to the base of Bunda Cliffs; T. Timmis and M. Daniels (AFMA) for providing historical fishery effort data; S. Childerhouse (Australian Marine Mammal Centre, AMMC) and S. Goldsworthy (SARDI) for reviewing several drafts; M. Sumner (University of Tasmania) for advice on analysis of spatial foraging data; S. Candy and J. McKinlay (Australian Antarctic Division, AAD) for advice on analysis of bycatch data; J. Fitzpatrick (AAD) for assistance with editing figures. We also gratefully acknowledge the funding support of the GABMP Steering Committee. Approval to conduct these activities was granted by the University of Adelaide Animal Ethics Committee (S-008-2007) and conducted under an SA Department of Environment and Heritage (DEH) permit (A-24684).

\section{LITERATURE CITED}

Adelaide Now (2011) Net ban protects SA's sea lions. Adelaide Now, the Advertiser, South Australia, 7 June 2011. Available at www.adelaidenow.com.au/news/southaustralia/net-ban-protects-sas-sea-lions/story-e6frea831226070587980 (accessed 30 July 2011)

Baylis AMM, Page B, Goldsworthy SD (2008) Effect of seasonal changes in upwelling activity on the foraging locations of a wide-ranging central-place forager, the New Zealand fur seal. Can J Zool 86:774-789

Baylis AMM, Hamer DJ, Nichols PD (2009) Assessing the use of milk fatty acids to infer the diet of the Australian sea lion (Neophoca cinerea). Wildl Res 36:169-176

Beverton RJH (1985) Analysis of marine mammal-fisheries interactions. In: Beddington JR, Beverton RJH, Lavigne DM (eds) Marine mammals and fisheries. George Allen \& Unwin, London, p 3-33

Bonner WN (1989) Seals and man - a changing relationship. Biol J Linn Soc 38:53-60

Campbell RA, Gales NJ, Lento GM, Baker CS (2008a) Islands in the sea: extreme female natal site fidelity in the Australian sea lion Neophoca cinerea. Biol Lett 4:139-142

Campbell RA, Holley D, Christianopoulos D, Caputi N, Gales NJ (2008b) Mitigation of incidental mortality of Australian sea lions in the west coast rock lobster fishery. Endang Species Res 5:345-358

Cochrane WG (1977) Sampling techniques, 3rd edn. John Wiley \& Sons, New York, NY

Costa DP, Gales NJ (2003) Energetics of a benthic diver: seasonal foraging ecology of the Australian sea lion, Neophoca cinerea. Ecol Monogr 73:27-43

Costa DP, Robinson PW, Arnould JPY, Harrison AL and others (2010) Accuracy of Argos locations of pinnipeds at-sea estimated using Fastloc GPS. PLoS ONE 5:e8677

David JHM, van Sittert L (2008) A reconstruction of the cape (South African) fur seal harvest 1653-1899 and a comparison with the 20th-century harvest. S Afr J Mar Sci 104: $107-112$

DEH (Department of the Environment and Heritage) (2005) Great Australian Bight Marine Park (Commonwealth Waters) Management Plan, 2005-2012. Department of the Environment and Heritage, Australian Government, Canberra

DEHAA (Department for Environment, Heritage and Aboriginal Affairs) (1999) Great Australian Bight Marine Park Management Plan, Part A: management prescriptions. Department for Environment, Heritage and Aboriginal Affairs, Government of South Australia, Adelaide

> Dennis TE, Shaughnessy PD (1996) Status of the Australian sea lion, Neophoca cinerea, in the Great Australian Bight. Wildl Res 23:741-754

DEWHA (Department of the Environment, Water, Heritage and the Arts) (2008) Australian sea lion (Neophoca cinerea). Conservation advice. Threatened species and threatened ecological communities. Department of the Environment, Water, Heritage and the Arts, Australian Government, Canberra. Available at www.environment. gov.au/biodiversity/threatened/species/neophoca-cinerea. html (accessed 9 March 2011)

Edgar GJ (2008) Australian marine life: the plants and animals of temperate waters, 2nd edn. New Holland Publishers, Chatswood

Edyvane KS (1998) Great Australian Bight Marine Park Management Plan, Part B: resource information. Department for Environment, Heritage and Aboriginal Affairs, Government of South Australia, Adelaide 
Fowler CW (1987) Marine debris and northern fur seals: a case study. Mar Pollut Bull 18:326-335

Fowler CW, Merrick R, Baker JD (1990) Studies of the population level effects of entanglement on northern fur seals. In: Shomura RS, Godfrey ML (eds) Proc 2nd Int Conf Mar Debris. Department of Commerce, Honolulu, HI, p 453-474

Fowler SL, Costa DP, Arnould JPY, Gales NJ, Kuhn CE (2006) Ontogeny of diving behaviour in the Australian sea lion: trials of adolescence in a late bloomer. J Anim Ecol 75:358-367

Fowler SL, Costa DP, Arnould JPY (2007) Ontogeny of movements and foraging ranges of the Australian sea lion. Mar Mamm Sci 23:598-614

Gales NJ, Cheal AJ (1992) Estimating diet composition of the Australian sea-lion (Neophoca cinerea) from scat analysis: an unreliable technique. Wildl Res 19:447-456

Gales NJ, Costa DP (1997) The Australian sea lion: a review of an unusual life history. In: Hindell M, Kemper C (eds) Marine mammal research in the Southern Hemisphere, Vol 1: status, ecology and medicine. Surrey Beatty \& Sons, Sydney, p 78-87

Gales NJ, Shaughnessy PD, Dennis TE (1994) Distribution, abundance and breeding cycle of the Australian sea lion, Neophoca cinerea (Mammalia: Pinnipedia). J Zool (Lond) 234:353-370

Gibson B (2008) Advice to SESSF concession holders: SESSF closures directions 2008. Reference F2008/0437. Australian Fisheries Management Authority, Canberra

Goldsworthy SD, Gales NJ (2008) Neophoca cinerea. In: International Union for the Conservation of Nature (IUCN) Red List of Threatened Species. Version 2010.3. Available at www.iucnredlist.org (accessed 4 October 2010)

Goldsworthy SD, Lowther AD (2010) Genetic population structure and bycatch: assessment of management measures for reducing the bycatch of Australian sea lions in the demersal gillnet fishery off South Australia. Report to the Department of Sustainability, Environment, Water, Population and Communities. SARDI publication no. F2010/000979-1, Report Series no. 515. Government of South Australia, Adelaide

Goldsworthy SD, Bulman C, He X, Larcombe J, Littnan C (2003) Trophic interactions between marine mammals and Australian fisheries: an ecosystem approach. In: Gales N, Hindell M, Kirkwood R (eds) Marine mammals: fisheries, tourism and management issues. CSIRO Publishing, Melbourne, p 62-99

Goldsworthy SD, Lowther A, Shaughnessy PD, McIntosh RR, Page B (2007) Assessment of pup production and the maternal investment strategies of the Australian sea lion Neophoca cinerea at Dangerous Reef in the 2006-07 breeding season. Report to Department for Environment \& Heritage. SARDI publication no. F2007/000929-1, Report Series no. 249. Government of South Australia, Adelaide

Goldsworthy SD, Page B, Shaughnessy, PD, Hamer DJ and others (2009a) Innovative solutions for aquaculture planning and development: addressing seal interactions in the finfish aquaculture industry. Report to Primary Industries and Resources South Australia (PIRSA) and Fisheries Research and Development Corporation (FRDC) Project no. 2004/201, SARDI, Adelaide

Goldsworthy SD, McKenzie J, Shaughnessy PD, McIntosh RR, Page B, Campbell RA (2009b) An update of the report: understanding the impediments to the growth of Australian sea lion populations. Report to the Department of the Environment, Water, Heritage and the Arts. SARDI publication no. F2008/000847-1, Report Series no. 356. Government of South Australia, Adelaide
Goldsworthy SD, Page B, Shaughnessy PD, Linnane A (2010) Mitigating seal interactions in the SRLF and gillnet sector SESSF in South Australia. Report to the Fisheries Research \& Development Corporation (FRDC). SARDI publication no. F2009/000613-1, Report Series no. 405. Government of South Australia, Adelaide

Hamer DJ (2007) Synthesis and review of fishery logbooks for the SA rock lobster and the Commonwealth SESSF gillnet fisheries: reports of interactions with seals. In: Goldsworthy SD, Hamer DJ, Page B (eds) Assessment of the implications of interactions between fur seals and sea lions and the SA southern rock lobster fishery (SARLF) and gillnet sector of the southern and eastern scalefish and shark fishery (SESSF) in South Australia. Report to Fisheries Research \& Development Corporation project no. 2005/077. South Australian Research \& Development Institute, Government of South Australia, Adelaide, p 21-25

Hamer DJ, Goldsworthy SD (2006) Seal-fishery operational interactions: identifying the environmental and operational aspects of a trawl fishery that contribute to by-catch and mortality of Australian fur seals (Arctocephalus pusillus doriferus). Biol Conserv 130:517-529

Hamer DJ, Page B, Goldsworthy SD (2007) The spatial distribution of foraging effort in Australian sea lion populations in close proximity to areas of high catch and effort in the SA rock lobsters and shark gill-net fisheries. In: Goldsworthy SD, Peters KJ, Page B (eds) Foraging ecology and diet analysis of Australian sea lions. Report to Department of the Environment \& Water Resources. SARDI publication no. F2007/001024-1, Report Series no. 251. Government of South Australia, Adelaide, p 19-31

Hamer DJ, Ward TM, McGarvey R (2008) Measurement, management and mitigation of operational interactions between the South Australian sardine fishery and shortbeaked common dolphins (Delphinus delphis). Biol Conserv 141:2865-2878

> Hamer DJ, Ward TM, McGarvey R (2009) Objective reporting of scientific results is critical for maintaining relationships with industry and achieving conservation outcomes for fisheries. Anim Conserv 12:287-288

Hamer DJ, Ward TM, Goldsworthy SD, Shaughnessy PD (2010) Mitigating the impact of shark gill-nets on Australian sea lions in South Australia using spatial management options. Report to the Fisheries Research \& Development Corporation (FRDC) project no. 2007/041, SARDI, Adelaide

> Harwood J (2001) Marine mammals and their environment in the twenty-first century. J Mammal 82:630-640

> Higgins LV (1993) The nonannual, nonseasonal breeding cycle of the Australian sea lion, Neophoca cinerea. J Mammal 74:270-274

Hooker SK, Gerber LR (2004) Marine reserves as a tool for ecosystem-based management: the potential importance of megafauna. Bioscience 54:27-39

Jaaman SA, Lah-Anyi YU, Pierce GJ (2009) The magnitude and sustainability of marine mammal by-catch in fisheries in East Malaysia. J Mar Biol Assoc UK 89 (Spec Issue 5 Cetaceans):907-920

Kuhn CE, Johnson DS, Ream RR, Gelatt TS (2009) Advances in the tracking of marine species: using GPS locations to evaluate satellite track data and a continuous-time movement model. Mar Ecol Prog Ser 393:97-109

Lavigne DM (1999) The Hawaiian monk seal: management of an endangered species. In: Twiss JR, Reeves RR (eds) Conservation and management of marine mammals. Melbourne University Press, Melbourne, p 246-266 
Ling JK (1999) Exploitation of fur seals and sea lions from Australian, New Zealand and adjacent subantarctic islands during the eighteenth, nineteenth and twentieth centuries. Aust Zool 31:323-350

Lopez A, Pierce GJ, Santos MB, Garcia J, Guerra A (2003) Fishery by-catches of marine mammals in Galician waters: results from on-board observations and an interview survey of fishermen. Biol Conserv 111:25-40

McIntosh RR, Page B, Goldsworthy SD (2006) Dietary analysis of regurgitates and stomach samples from free-living Australian sea lions. Wildl Res 33:661-669

Murphy P, Richardson G (2002) Assessment report: southern and eastern scalefish and shark fishery. Australian Fisheries Management Authority (AFMA), Australian Government, Canberra

NHT (National Heritage Trust) (2005) Draft Great Australian Bight Marine Park (Commonwealth waters and state waters) description of values and uses. Department of the Environment and Heritage, Australian Government, Canberra

Page B, McKenzie J, McIntosh RR, Baylis AMM and others (2004) Entanglement of Australian sea lions and New Zealand fur seals in lost fishing gear and other marine debris before and after government and industry attempts to solve the problem. Mar Pollut Bull 49:33-42

Peters KJ, Ophelkeller K, Goldsworthy SD (2007) Developing molecular DNA techniques to determine the diet of Australian sea lions. In: Goldsworthy SD, Peters KJ, Page B (eds) Foraging ecology and diet analysis of Australian sea lions. Report to Department of the Environment and Water Resources. SARDI publication no. F2007/001024-1, Report Series no. 251. Government of South Australia, Adelaide, p 111-134

Pires R, Neves HC, Caramandilis AA (2008) The critically endangered Mediterranean monk seal Monachus monachus in the archipelago of Madeira: priorities for conservation. Oryx 42:278-285

Robinson AC, Armstrong DM, Canty PD, Hopton D, Medlin GC, Shaughnessy PD (2008) Investigator Group expedition 2006: vertebrate fauna. Trans R Soc S Aust 132: 221-242

Shaughnessy PD, Kirkwood R, Cawthorn M, Kemper C, Pemberton D (2003) Pinnipeds, cetaceans and fisheries in Australia: a review of operational interactions. In: Gales N, Hindell M, Kirkwood R (eds) Marine mammals: fisheries, tourism and management issues. CSIRO Publishing, Melbourne, p 136-152

Shaughnessy PD, Dennis TE, Seager PG (2005) Status of Australian sea lions, Neophoca cinerea, and New Zealand fur seals, Arctocephalus forsteri, on Eyre Peninsula and the

Editorial responsibility: David Agnew,

London, United Kingdom far west coast of South Australia. Wildl Res 32:85-101

Shaughnessy PD, McIntosh RR, Goldsworthy SD, Dennis TE, Berris M (2006) Trends in abundance of Australian sea lions, Neophoca cinerea, at Seal Bay, Kangaroo Island, South Australia. In: Trites AW, Atkinson SK, DeMaster DP, Fritz LW, Gelatt TS, Rea LD, Wynne KM (eds) Sea lions of the world. Alaska Sea Grant College Program, University of Alaska, Fairbanks, AK, p 37-63

Shaughnessy PD, Goldsworthy SD, Hamer DJ, Page B, McIntosh RR (2011) Australian sea lions Neophoca cinerea at colonies in South Australia: distribution, abundance and trends, 2004 to 2008. Endang Species Res 13:87-98

> Slooten E, Rayment W, Dawson S (2006) Offshore distribution of Hector's dolphin at Banks Peninsula, New Zealand: Is the Banks Peninsula Marine Mammal Sanctuary large enough? NZ J Mar Freshw Res 40:333-343

Sterling JT, Ream RR (2004) At-sea behaviour of juvenile male northern fur seals (Callorhinus ursinus). Can J Zool 82:1621-1637

> Taylor RH (1982) New Zealand fur seals in the Bounty Islands. NZ J Mar Freshw Res 16:1-9

Wade PR (1998) Calculating thresholds to the human-caused mortality of cetaceans and pinnipeds. Mar Mamm Sci 14: $1-37$

> Walker TI, Hudson RJ, Gason AS (2005) Catch evaluation of target, by-product and by-catch species taken by gillnets and longlines in the shark fishery of south-eastern Australia. J Northwest Atl Fish Sci 35:505-530

Warneke RM (1982) The distribution and abundance of seals in the Australasian region, with summaries of biology and current research. Mammals in the seas, Fisheries Series no. 5, Vol 2. Food and Agriculture Organisation, Rome, p 431-475

Wickens PA (1995) A review of operational interactions between pinnipeds and fisheries. Food and Agriculture Organisation, Fisheries Technical Paper, Vol 346. Food and Agriculture Organisation, Rome

Wickens PA, David JHM, Shelton PA, Field JG (1991) Trends in harvests and pup numbers of the South African fur seal: implications for management. S Afr J Mar Sci 11:307-326

Wilkinson IS, Burgess J, Cawthorn M (2003) New Zealand sea lions and squid: managing fisheries impacts on a threatened marine mammal. In: Gales N, Hindell M, Kirkwood R (eds) Marine mammals: fisheries, tourism and management issues. CSIRO Publishing, Melbourne, p 192-207

Woodley TH, Lavigne DM (1991) The incidental capture of pinnipeds in commercial fishing gear. Tech Rep 91-01, International Marine Mammal Association

Zar JH (1999) Biostatistical analysis, 4th edn. Prentice Hall, Upper Saddle River, NJ

Submitted: September 15, 2010; Accepted: April 27, 2011 Proofs received from author(s): August 29, 2011 